\title{
Psoriasis. Diagnostic and therapeutic recommendations of the Polish Dermatological Society. Part I: Mild psoriasis
}

\author{
Łuszczyca. Rekomendacje diagnostyczno-terapeutyczne Polskiego Towarzystwa \\ Dermatologicznego. Część l: łuszczyca łagodna
}

\author{
Adam Reich', Zygmunt Adamski², Grażyna Chodorowska³, Andrzej Kaszuba ${ }^{4}$, Dorota Krasowska ${ }^{3}$, \\ Aleksandra Lesiak ${ }^{4}$, Joanna Maj ${ }^{5}$, Joanna Narbutt ${ }^{4}$, Agnieszka Osmola-Mańkowska², \\ Agnieszka Owczarczyk-Saczonek ${ }^{6}$, Witold Owczarek ${ }^{7}$, Waldemar Placek ${ }^{6}$, Lidia Rudnicka ${ }^{8}$, Jacek Szepietowski ${ }^{5}$ \\ 'Department of Dermatology, University of Rzeszow, Poland \\ 2Department of Dermatology, Poznan University of Medical Sciences, Poland \\ ${ }^{3}$ Department of Dermatology, Venereology and Paediatric Dermatology, Medical University of Lublin, Poland \\ ${ }^{4}$ Department of Dermatology, Paediatric and Oncologic Dermatology, Medical University of Lodz, Poland \\ ${ }^{5}$ Department of Dermatology, Venereology and Allergology, Wroclaw Medical University, Poland \\ ${ }^{6}$ Department of Dermatology, Sexually Transmitted Diseases and Clinical Immunology, University of Warmia and Mazury \\ in Olsztyn, Poland \\ ${ }^{7}$ Department of Dermatology, Military Institute of Health Services, Warsaw, Poland \\ ${ }^{8}$ Department of Dermatology, Medical University of Warsaw, Poland \\ 'Zakład i Klinika Dermatologii Uniwersytetu Rzeszowskiego w Rzeszowie, Polska \\ ${ }^{2}$ Katedra i Klinika Dermatologii Uniwersytetu Medycznego w Poznaniu, Polska \\ ${ }^{3}$ Katedra i Klinika Dermatologii, Wenerologii i Dermatologii Dziecięcej Uniwersytetu Medycznego w Lublinie, Polska \\ ${ }^{4}$ Katedra i Klinika Dermatologii, Dermatologii Dziecięcej i Onkologicznej Uniwersytetu Medycznego w Łodzi, Polska \\ ${ }^{5}$ Katedra i Klinika Dermatologii, Wenerologii i Alergologii Uniwersytetu Medycznego we Wrocławiu, Polska \\ ${ }^{6}$ Katedra i Klinika Dermatologii, Chorób Przenoszonych Drogą Płciową i Immunologii Uniwersytetu Warmińsko-Mazurskiego \\ w Olsztynie, Polska \\ ${ }^{7}$ Klinika Dermatologii Wojskowego Instytutu Medycznego w Warszawie, Polska \\ ${ }^{8}$ Katedra i Klinika Dermatologiczna Warszawskiego Uniwersytetu Medycznego, Polska
}

Dermatol Rev/Przegl Dermatol 2018, 105, 225-243

DOI: https://doi.org//0.5/|4/dr.2018.75580

CORRESPONDING AUTHOR/ ADRES DO KORESPONDENCJI: prof. dr hab. n. med. Adam Reich Zakład i Klinika Dermatologii Uniwersytet Rzeszowski ul. Szopena 2

35-055 Rzeszów, Polska tel.: +48605076722

e-mail: adi_medicalis@go2.pl

\begin{abstract}
Psoriasis is a chronic inflammatory skin disease affecting approximately $1-3 \%$ of the general population. Recent years have brought a considerable progress in the treatment of this dermatosis, particularly with respect to patients with moderate to severe psoriasis. A growing range of increasingly available systemic therapies poses new challenges to physicians providing care to patients with psoriasis. On account of the fact that new antipsoriatic drugs have become available on the pharmaceutical market since the publication of previous guidelines for the treatment of psoriasis, an update has become necessary. The first part of the guidelines refers to mild psoriasis and selected special forms of this disease. The aim of the recommendations of the Polish Dermatological Society is to summarize the most recent literature reports and formulate guidelines that may be potentially useful for dermatologists-venereologists in their daily clinical practice. However, the final decision regarding the diagnostic and therapeutic procedure should always be made individually for each patient based on the patient's current clinical status and the most up-to-date literature reports.
\end{abstract}




\section{STRESZCZENIE}

Łuszczyca jest przewlekłą chorobą zapalną skóry dotyczącą ok. 1-3\% ogólnej populacji. Ostatnie lata przyczyniły się do znacznego postępu w leczeniu tej dermatozy, zwłaszcza u pacjentów z łuszczycą o umiarkowanym i dużym nasileniu. Coraz liczniejsze i powszechniej dostępne możliwości leczenia ogólnego stawiają nowe wyzwania przed lekarzami sprawującymi opiekę nad chorymi na łuszczycę. Ze względu na nowe leki, które pojawiły się na rynku farmaceutycznym od czasu opublikowania poprzednich zaleceń dotyczących leczenia łuszczycy, zaistniała potrzeba uaktualnienia dotychczas obowiązujących wytycznych. Pierwsza część wytycznych dotyczy łuszczycy łagodnej oraz wybranych szczególnych form tej choroby. Celem rekomendacji Polskiego Towarzystwa Dermatologicznego jest podsumowanie współczesnych danych z piśmiennictwa oraz sformułowanie wskazówek, które mogą być przydatne w codziennej praktyce klinicznej dermatologów-wenerologów. Należy jednocześnie zaznaczyć, że każda decyzja dotycząca postępowania diagnostyczno-terapeutycznego u pacjenta musi być podjęta indywidualnie z uwzględnieniem aktualnego stanu klinicznego, a także na podstawie bieżących doniesień naukowych.

Key words: diagnostics, treatment, psoriasis, guidelines.

Słowa kluczowe: diagnostyka, leczenie, łuszczyca, wytyczne.

\section{INTRODUCTION}

Psoriasis is a chronic inflammatory skin disease affecting approximately $1-3 \%$ of the general population [1]. It is estimated that in about $70-80 \%$ of patients psoriatic skin lesions are mild and require only topical treatment. In the remaining patients the severity of lesions is more pronounced, and it is necessary to introduce phototherapy and quite frequently also systemic treatment. According to estimates, approximately $5-30 \%$ of patients with psoriasis develop psoriatic arthritis. Importantly, joint disease may affect both patients with severe skin involvement and with only isolated psoriatic lesions identified on the skin and/or nails [1]. Psoriasis is known to have a significant adverse effect on the quality of life of affected individuals, and patients with psoriasis present with impaired physical and mental functioning. People with psoriasis are commonly socially withdrawn. They avoid attending public swimming pools, saunas and showers, as well as sunbathing, practising sports or even visiting the hairdresser. Psoriasis also adversely affects the sexual life of patients. The aetiology of the disease still has not been fully elucidated. Recent research, however, has yielded a multitude of new insights into the pathomechanism of psoriasis and its comorbidities, but above all contributed to the introduction of a range of new therapeutic methods.

With rapid expansion of knowledge and changes on the market of currently available antipsoriatic drugs, a need has arisen to update previous recommendations of the Polish Dermatological Society for

\section{WPROWADZENIE}

Łuszczyca jest przewlekłą chorobą zapalną skóry dotyczącą ok. 1-3\% ogólnej populacji [1]. Szacuje się, że u 70-80\% pacjentów zmiany skórne mają niewielkie nasilenie i wymagają jedynie stosowania leków miejscowych. U pozostałych pacjentów nasilenie zmian jest większe i konieczne bywa wdrożenie fototerapii, a nierzadko także leczenia ogólnego. Ocenia się, że u ok. 5-30\% pacjentów z łuszczycą występuje łuszczycowe zapalenie stawów, przy czym choroba stawów może pojawić się zarówno u pacjentów z nasilonymi zmianami skórnymi, jak i u tych chorych, u których widoczne są jedynie pojedyncze ogniska łuszczycy na skórze i/lub paznokciach [1]. Wykazano, że łuszczyca istotnie obniża jakość życia, a u chorych stwierdza się ograniczenie sprawności fizycznej i funkcjonowania psychicznego. Często są oni wycofani społecznie, unikają korzystania z pływalni, wspólnych łaźni i pryszniców, opalania się, uprawiania sportu czy rezygnują nawet $\mathrm{z}$ wizyty $\mathrm{u}$ fryzjera. Łuszczyca negatywnie oddziałuje także na życie seksualne chorych. Etiologia choroby nadal nie jest w pełni poznana, ale ostatnie lata przyniosły wiele nowych danych na temat patomechanizmu łuszczycy i schorzen współistniejących, a przede wszystkim zaowocowały wdrożeniem licznych nowych metod terapeutycznych.

Szybki postęp wiedzy i zmiany na rynku leków przeciwłuszczycowych wiążą się z koniecznością uaktualnienia dotychczas obowiązujących zaleceń Polskiego Towarzystwa Dermatologicznego dotyczących leczenia 
the treatment of this nosological entity [2-4]. We are presenting a new set of recommendations for the diagnostic and therapeutic management of patients with psoriasis. Some of the guidelines are the same as in the previous edition, however others had to be revised, mostly with regard to biologic drugs, as this drug group has seen the greatest advances in recent years. On account of the broad scope of the guidelines, they were divided into two parts. The first part addresses mild psoriasis and selected special types of the disease, and the second part presents recommendations regarding systemic treatment of moderate to severe psoriasis. The authors of the document hope that the recommendations will assist practising physicians in their diagnostic and therapeutic decisions in the process of providing care to patients with psoriasis. At the same time, however, we want to stress that the recommendations are general in nature and do not cover all possible clinical situations. The final decision regarding the use of a particular therapy or diagnostic procedure is always made by the physician having direct contact with the patient.

\section{PROCEDURE FOR THE DEVELOPMENT}

\section{OF GUIDELINES}

The guidelines have been developed by a group of experts selected by the Board of the Polish Dermatological Society. The process of preparing the guidelines consisted of multiple stages and was based on extensive consultations. Following a strategy meeting of the experts and the development of a draft version (by A.R.), the document was sent to all team members to receive feedback on the proposed recommendations. After incorporating comments, a revised version of the recommendations was prepared and again sent for consultation and approval. Further feedback was received and discussed, and based on the outcome the final version of the manuscript was completed. Following the team's approval, the document was submitted for printing. The English version was prepared by a translator and corrected by the team members (L.R., A.R.). Then both versions were checked for language errors by the editorial team.

\section{DIAGNOSIS OF PSORIASIS}

In typical cases psoriasis is diagnosed by assessing the morphology of skin lesions and their characteristic distribution involving most commonly the scalp, extensor surfaces of elbows and knees, sacral area and nails. If there are doubts about the clinical diagnosis, a skin biopsy should be obtained from a pathological lesion and the diagnosis should be verified histologically. Dermoscopy may be useful in some cases. tej jednostki chorobowej [2-4]. Przekazujemy Państwu nowe zalecenia dotyczące postępowania diagnostycznego i terapeutycznego u chorych na łuszczycę - w części będą one powtórzeniem poprzednich zaleceń, ale $\mathrm{w}$ wielu sytuacjach konieczne było zmodyfikowanie dotychczas obowiązujących wytycznych, przede wszystkim w przypadku leków biologicznych, gdyż to właśnie w tej grupie leków obserwuje się w ostatnich latach największy postęp. Zalecenia zostały podzielone na dwie części, z których pierwsza obejmuje wytyczne dotyczące łuszczycy łagodnej i wybranych szczególnych postaci tej choroby, natomiast w drugiej części zostały przedstawione zalecenia dotyczące leczenia ogólnego łuszczycy umiarkowanej do ciężkiej. Autorzy niniejszego opracowania mają nadzieję, że przedstawione zalecenia pomogą praktykującym lekarzom w podejmowaniu decyzji diagnostycznych i leczniczych w trakcie opieki nad chorymi na łuszczycę. Jednocześnie pragniemy podkreślić, że przedstawione zalecenia mają charakter ogólny i nie obejmują wszystkich możliwych sytuacji klinicznych. Ostateczna decyzja dotycząca zastosowania poszczególnych opcji leczniczych lub wdrożenia postępowania diagnostycznego należy do lekarza prowadzącego pacjenta.

\section{ZASADY OPRACOWANIA WYTYCZNYCH}

Niniejsze wytyczne zostały opracowane przez grupę ekspertów wybranych przez Zarząd Główny Polskiego Towarzystwa Dermatologicznego. Proces ich przygotowania przebiegał wieloetapowo i poprzez liczne konsultacje. Po ustaleniu wstępnej koncepcji w czasie spotkania zespołu oraz przygotowaniu wstępnej wersji pracy (przez A.R.) rozesłano ją do wszystkich członków zespołu w celu uzyskania komentarzy do proponowanych zaleceń. Po uwzględnieniu zgłoszonych uwag przygotowano kolejną wersję zaleceń, którą rozesłano do ponownego przeczytania i akceptacji. Po zapoznaniu się z kolejnymi uwagami i ponownym przedyskutowaniu przygotowano ostateczną wersję manuskryptu, którą po akceptacji zespołu i wprowadzeniu kolejnych poprawek uzgodnionych z członkami wysłano do druku. Wersja anglojęzyczna została przygotowana przez tłumacza oraz poprawiona przez członków zespołu (L.R., A.R.).

\section{ROZPOZNANIE ŁUSZCZYCY}

Rozpoznanie łuszczycy w typowych przypadkach opiera się na ocenie morfologii zmian skórnych oraz charakterystycznego umiejscowienia wykwitów (skóra owłosiona głowy, łokci i kolan, okolica krzyżowa, paznokcie). W przypadku wątpliwości co do rozpoznania klinicznego wskazane jest badanie histologiczne wycinka ze zmian skórnych w celu weryfikacji rozpoznania. W niektórych przypadkach choroby może być przydatna dermoskopia. 


\section{Recommendation I}

- Psoriasis is diagnosed on the basis of clinical features when the clinical presentation is unequivocal.

- Dermoscopy may be used as a supportive diagnostic method.

- Histological assessment of a skin specimen should be performed in ambiguous cases.

\section{COMORBIDITIES}

In view of the fact that some patients with psoriasis develop psoriatic arthritis (PA, arthropatic psoriasis) in the course of the disease, and the available data show that joint complaints in this group of patients are often misdiagnosed or diagnosed after a considerable delay [5, 6], all patients with psoriasis should be assessed for PA once a year. The diagnosis of PA can be facilitated by the generally available diagnostic criteria; at present some of the most commonly used criteria are the CASPAR criteria for psoriatic arthritis [7]. In cases of suspected PA consultation with a rheumatologist is recommended to verify the diagnosis. Basic laboratory tests (e.g. rheumatoid factor, ESR, CRP) and imaging examinations (ultrasound scan of involved joints, MRI, X-ray of bone structures, bone scintigraphy) must also be performed in order to assess disease activity and exclude other disorders of the motor system. It should be noted that in some patients PA may present solely as enthesitis or dactilitis, particularly in the early stage of the disease. Also, in some cases PA may occur in the axial form imitating ankylosing spondylitis or follow a course similar to rheumatoid arthritis.

\section{Recommendation II}

- All patients with psoriasis should be assessed for psoriatic arthritis anually.

A number of epidemiological studies have shown more frequent coexistence of metabolic disorders (insulin resistance, atherogenic dyslipidaemia, arterial hypertension and cardiovascular diseases) in patients with psoriasis, particularly in cases with a severe course of the disease [8]. In fact, psoriasis and atheromatosis are known to share the same pathogenetic mechanism, which is reflected in the concept of "psoriatic march" [9]. Patients with severe psoriasis exhibit a twice-higher prevalence of obesity, which leads to an increased secretion of metabolically active adipokines. The concentration of these compounds is correlated with the severity of the disease process and has an influence on the devel-

\section{Zalecenia I}

- Rozpoznanie łuszczycy ustala się na podstawie obrazu klinicznego w przypadkach, w których nie budzi on wątpliwości.

- Dermoskopia może być diagnostyczną metodą uzupełniającą.

- Badanie histologiczne wycinka skóry powinno być wykonane w przypadkach budzących wątpliwości diagnostyczne.

\section{CHOROBY WSPÓŁISTNIEJACE}

Ze względu na to, że u części pacjentów z łuszczycą $\mathrm{w}$ trakcie przebiegu choroby obserwuje się łuszczycowe zapalenie stawów (ŁZS, łuszczycę stawową), a także ze względu na dane świadczące o tym, że dolegliwości stawowe są $\mathrm{w}$ tej grupie chorych nierzadko diagnozowane błędnie lub z dużym opóźnieniem $[5,6]$, wszyscy pacjenci z łuszczycą raz w roku powinni być oceniani pod kątem ewentualnego wystąpienia $Ł Z S$. W rozpoznaniu ŁZS mogą być pomocne ogólnodostępne kryteria ŁZS obecnie do najczęściej stosowanych zalicza się kryteria CASPAR [7]. Jeśli podejrzewamy ŁZS, wskazana jest konsultacja reumatologiczna, aby potwierdzić rozpoznanie. Konieczne jest także wykonanie podstawowych badań laboratoryjnych (m.in. czynnik reumatoidalny, OB, CRP) oraz obrazowych (m.in. ultrasonografia zajętych stawów, rezonans magnetyczny, rentgenogram struktur kostnych, scyntygrafia kości) do oceny aktywności choroby oraz wykluczenia innych schorzeń układu ruchu. Należy pamiętać, że u części pacjentów ŁZS, zwłaszcza na początku, może przebiegać jedynie jako zapalenie przyczepów ścięgnistych (enthesitis) i/lub palców (dactilitis). Część przypadków ŁZS może także przebiegać w postaci osiowej, imitującej zesztywniające zapalenia stawów kręgosłupa lub też mieć postać podobną do reumatoidalnego zapalenia stawów.

\section{Zalecenia II \\ - Wszyscy pacjenci z łuszczycą raz w roku po- winni być oceniani pod kątem ewentualnego wystąpienia łuszczycowego zapalenia stawów.}

Liczne badania epidemiologiczne dowodzą częstszego współistnienia zaburzeń metabolicznych (insulinooporności, dyslipidemii aterogennej, nadciśnienia tętniczego i chorób układu sercowo-naczyniowego) u chorych na łuszczycę, zwłaszcza o ciężkim przebiegu [8]. Okazuje się, że łuszczyca i miażdżyca mają podobny mechanizm patogenetyczny, który znalazł swoje odzwierciedlenie w koncepcji marszu łuszczycowego [9]. Ponad dwukrotnie częstsze występowanie otyłości u chorych na łuszczycę o ciężkim przebiegu warunkuje większe wydzielanie aktywnych metabolicznie adipokin, których stężenie koreluje 
opment of further metabolic disorders [10]. This results in a higher incidence of cardiovascular diseases and increased cardiovascular mortality in the group of patients with psoriasis $[11,12]$. The findings demonstrate that psoriasis should be treated as a systemic inflammatory process, and dermatologists are expected not only to treat skin lesions but also diagnose and monitor coexisting disorders. It must be stressed that early introduction of appropriate therapy may prevent the development of concomitant metabolic disorders.

Patients with psoriasis, particularly with a severe course of the disorder, are at a high risk of developing cardiovascular diseases. Consequently, they should be screened for these diseases at least once a year (table 1) [13]. Moreover, concomitant metabolic disorders in patients with psoriasis significantly increase the risk of adverse reactions of systemic therapy with conventional drugs, and reduce the efficacy of biological treatment. z nasileniem procesu chorobowego i wpływa na rozwój dalszych zaburzeń metabolicznych [10]. Skutkuje to większą zapadalnością chorych z łuszczycą na choroby układu sercowo-naczyniowego oraz zwiększoną śmiertelnością z tego powodu [11, 12]. Obserwacje te wskazują, że łuszczycę należy traktować jako ogólnoustrojowy proces zapalny, a obowiązkiem dermatologa jest nie tylko leczenie zmian skórnych, lecz także diagnostyka i monitorowanie współistniejących zaburzeń. Należy podkreślić, że wczesne podjęcie odpowiedniego leczenia może zapobiegać rozwojowi towarzyszących zaburzeń metabolicznych.

Chorzy na łuszczycę, zwłaszcza o ciężkim przebiegu, należą do grupy wysokiego ryzyka rozwoju chorób sercowo-naczyniowych, dlatego zaleca się kontrolowanie ich w tym kierunku przynajmniej raz w roku (tab. 1) [13]. Ponadto współistniejące zaburzenia metaboliczne istotnie zwiększają ryzyko wystąpienia niepożądanych objawów leczenia ogólnego lekami konwencjonalnymi, zmniejszają skuteczność leczenia biologicznego.

Table I. Goals related to risk factors and target (desirable) levels of major cardiovascular risk factors according to the 2016 guidelines of the European Society of Cardiology [13]

\begin{tabular}{|c|c|}
\hline Risk factor & Goal and target value \\
\hline Smoking & Exposure to all forms of smoking is absolutely contraindicated \\
\hline Diet & Low in saturated fats, based primarily on wholegrain products, vegetables, fruit and fish \\
\hline Physical activity & $\begin{array}{l}\geq 150 \mathrm{~min} / \text { week of moderate aerobic physical activity ( } 30 \mathrm{~min} 5 \text { times a week) or } 75 \mathrm{~min} / \text { week of vigorous } \\
\text { aerobic physical activity ( } 15 \mathrm{~min} 5 \text { times a week) or a combination of the above }\end{array}$ \\
\hline Body weight & Body mass index (BMI) 20-25 kg/m²; waist circumference $<94 \mathrm{~cm}$ (men) or $<80 \mathrm{~cm}$ (women) \\
\hline $\mathrm{BP}$ & $<140 / 90 \mathrm{~mm} \mathrm{Hg}$ \\
\hline $\begin{array}{l}\text { Lipids: } \\
\text { - LDL is the primary } \\
\text { target } \\
\text { - HDL cholesterol } \\
\text { - Triglycerides }\end{array}$ & $\begin{array}{l}\text { Target LDL concentration } \leq 2.6 \mathrm{mmol} / \mathrm{l}(\leq 100 \mathrm{mg} / \mathrm{dl}) \\
\text { No target value, however }>1.0 \mathrm{mmol} / /(>40 \mathrm{mg} / \mathrm{dl}) \text { in men and }>1.2 \mathrm{mmol} / /(>45 \mathrm{mg} / \mathrm{dl}) \text { in women } \\
\text { are markers of reduced risk } \\
\text { No target value, however }<1.7 \mathrm{mmol} / /(<150 \mathrm{mg} / \mathrm{dl}) \text { is a marker of reduced risk, and high concentration } \\
\text { requires identification of other risk factors }\end{array}$ \\
\hline Diabetes & Glycated haemoglobin $<7 \%(<53 \mathrm{mmol} / \mathrm{mol})$ \\
\hline
\end{tabular}

Tabela I. Cele związane z czynnikami ryzyka i docelowe (pożądane) poziomy istotnych czynników ryzyka sercowo-naczyniowego wg wytycznych European Society of Cardiology z 2016 r. [13]

\begin{tabular}{|c|c|}
\hline Czynnik ryzyka & Cel i docelowa wartość \\
\hline palenie tytoniu & bezwzględnie przeciwwskazane narażanie na ekspozycję na tytoń w jakiejkolwiek formie \\
\hline dieta & uboga w tłuszcze nasycone, zawierająca głównie produkty pełnoziarniste, warzywa, owoce i ryby \\
\hline wysiłek fizyczny & $\begin{array}{l}\text { z I } 50 \text { min tygodniowo umiarkowanego, tlenowego wysitku fizycznego ( } 30 \text { min przez } 5 \text { dni w tygodniu) } \\
\text { lub } 75 \text { min tygodniowo energicznego, tlenowego wysitku fizycznego (I } 5 \text { min przez } 5 \text { dni w tygodniu) } \\
\text { lub połączenie powyższych }\end{array}$ \\
\hline masa ciała & wskaźnik masy ciała (BMI) 20-25kg/m²; obwód pasa < 94 cm (mężczyźni) lub < 80 cm (kobiety) \\
\hline ciśnienie tętnicze & $<140 / 90 \mathrm{~mm} \mathrm{Hg}$ \\
\hline $\begin{array}{l}\text { lipidy: } \\
\text { - LDL jest celem } \\
\text { pierwszorzędowym } \\
\text { - cholesterol frakcji } \\
\text { HDL } \\
\text { - triglicerydy }\end{array}$ & 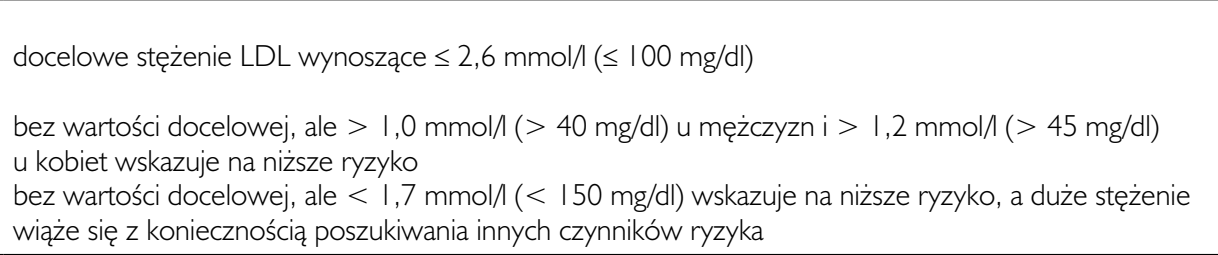 \\
\hline cukrzyca & hemoglobina glikowana $<7 \%(<53 \mathrm{mmol} / \mathrm{mol})$ \\
\hline
\end{tabular}




\section{ASSESSMENT OF PSORIASIS SEVERITY}

There is, as yet, no full consensus on the classification of psoriasis vulgaris depending on the degree of disease severity, though recent years have seen widespread application of the so-called "rule of tens". In line with that rule, psoriasis is considered mild in cases when skin lesions cover less than $10 \%$ of the total body surface area (BSA $<10 \%$ ), their severity determined using the psoriasis area severity index (PASI) is less than 10, and the negative impact of the disease on the quality of life of patients is, at most, moderate (Dermatology Life Quality Index - DLQI score < 10). All other cases of psoriasis vulgaris, i.e. those with BSA $\geq 10 \%$ or PASI score $\geq 10$ or DLQI score $\geq 10$, should be treated as psoriasis of at least moderate severity. In patients who cannot or are unable to complete the DLQI questionnaire (for example some patients with mental impairment) the severity of psoriasis can be assessed on the basis of PASI and BSA. The above classification implicates that all physicians actively involved in the treatment administered to patients with psoriasis must be familiar with the above indices. At present, there are no sufficient data to clearly discriminate between moderate and severe psoriasis [14]. As a result, all drugs with severe psoriasis included as a therapeutic indication in their summary of product characteristics may be used in the treatment of patients meeting the criteria of moderate to severe psoriasis. Also, systemic treatment may be indicated in special clinical situations even if patients do not meet the criteria of moderate to severe psoriasis. Such special circumstances include, for example, significant involvement of the skin in visible areas, pronounced involvement of the scalp, involvement of the genital region, significant involvement of hands and/or feet or the inability to work because of psoriatic lesions.

It needs to be noted that the above indices and criteria apply to psoriasis vulgaris and in particular to plaque psoriasis. However, their applicability in most cases of other forms of psoriasis is limited. The above holds especially for pustular psoriasis. All variants of pustular psoriasis, both within the categories of generalized and localized pustular psoriasis (palmoplantar pustolosis, acrodermatitis continua), may require the use of systemic medications, particularly in cases when an attempt at therapy with topical drugs fails to bring the desired results. Also, all cases of active PA require the initiation of systemic therapy. Similarly, topical agents are often insufficient in the treatment of isolated nail psoriasis, and patients require systemic therapy. After unsuccessful topical therapy, the presence of severe nail lesions (onycholysis with

\section{OCENA NASILENIA ŁUSZCZYCY}

Obecnie nie ma pełnej zgodności dotyczącej podziału łuszczycy zwykłej w zależności od jej ciężkości, choć ostatnio utrwaliła się tzw. reguła dziesiątek. Zgodnie z tą regułą za łuszczycę łagodną uznaje się wszystkie przypadki, w których zmiany skórne nie zajmują więcej niż $10 \%$ całkowitej powierzchni ciała (body surface area - BSA $<10 \%$ ), ich nasilenie określone wskaźnikiem PASI (Psoriasis Area and Severity Index) nie przekracza $10 \mathrm{pkt}$, a negatywny wplyw choroby na jakość życia pacjentów jest co najwyżej umiarkowany (jakość życia oceniona wskaźnikiem Dermatology Life Quality Index - DLQI $<10 \mathrm{pkt}$ ). Wszystkie inne przypadki łuszczycy zwykłej, czyli takie, w których BSA $\geq 10 \%$ lub PASI $\geq 10$ pkt, lub DLQI $\geq 10$ pkt, należy traktować jako łuszczycę o przynajmniej umiarkowanym nasileniu. U chorych, którzy nie mogą lub nie potrafią wypełnić kwestionariusza DLQI (np. niektórzy chorzy psychicznie), ocenę ciężkości łuszczycy można oprzeć jedynie na wskaźnikach PASI i BSA. Powyższa kategoryzacja implikuje konieczność zaznajomienia się z powyższymi wskaźnikami przez każdego lekarza leczącego pacjentów z łuszczycą. Obecnie nie ma wystarczających danych pozwalających na wyraźne odgraniczenie łuszczycy umiarkowanej od ciężkiej [14]. Z tego powodu wszystkie leki, które w charakterystyce produktu leczniczego mają wpisaną łuszczycę ciężką jako wskazanie do ich zastosowania, mogą być aplikowane u wszystkich pacjentów spełniających kryteria łuszczycy umiarkowanej do ciężkiej. W szczególnych sytuacjach klinicznych może być wskazane leczenie ogólne, nawet jeśli pacjent nie spełnia kryterium łuszczycy umiarkowanej do ciężkiej. Są to m.in. istotne zajęcie przez chorobę widocznych okolic ciała, nasilone zajęcie skóry owłosionej głowy, zajęcie okolic narządów płciowych, istotne zajęcie rąk i/lub stóp lub też niemożliwość wykonywania pracy zawodowej z powodu zmian łuszczycowych.

Należy wspomnieć, że powyższe wskaźniki i kryteria odnoszą się do łuszczycy zwykłej, zwłaszcza do łuszczycy plackowatej. W większości przypadków innych postaci łuszczycy mają one ograniczone zastosowanie. Dotyczy to zwłaszcza łuszczycy krostkowej. Wszystkie odmiany łuszczycy krostkowej, zarówno łuszczyca krostkowa uogólniona, jak i łuszczyca krostkowa ograniczona (łuszczyca krostkowa dłoni i stóp, zapalenie ciągłe krostkowe kończyn) mogą wymagać zastosowania leków ogólnych, zwłaszcza gdy próba terapii lekami miejscowymi nie przyniosła spodziewanych rezultatów. Również wszystkie przypadki aktywnego ŁZS wymagają rozpoczęcia terapii ogólnej. Podobnie w przypadku izolowanej łuszczycy paznokci leki miejscowe często są niewystarczające i pacjenci muszą stosować leki ogólne. Wskazaniem do rozpoczęcia leczenia ogólnego, przy niepowodzeniu terapii miej- 
subungual hyperkeratosis or dystrophy involving $\geq 50 \%$ of the nail plate area, with at least three finger nail plates affected) is an indication to initiate systemic treatment [15].

\section{Recommendation III}

- Mild psoriasis vulgaris

Mild psoriasis vulgaris is diagnosed when the patient's score in every evaluation (PASI, BSA and DLQI) is less than 10.

- Moderate to severe psoriasis vulgaris

Moderate to severe psoriasis vulgaris is diagnosed when the patient's score in at least one of the indices (PASI, BSA or DLQI) is 10 or more.

- Patients with mild psoriasis often require only topical treatment, possibly combined with phototherapy. The rule may not be applicable to patients with lesions in the socalled special locations (nails, scalp, anogenital area). Patients with moderate to severe psoriasis should be treated with phototherapy or systemic drugs, except for situations when they do not consent to this treatment regimen or in case of contraindications. scowej, jest obecność nasilonych zmian paznokciowych (onycholiza z podpaznokciową hiperkeratozą lub dystrofia obejmująca $\geq 50 \%$ powierzchni płytki) w obrębie przynajmniej 3 płytek paznokciowych palców rąk [15].

\section{Zalecenia III \\ - Łuszczyca zwykła o nasileniu łagodnym \\ Rozpoznanie łuszczycy zwykłej o nasileniu łagod- nym ustala się, gdy pacjent nie uzyskuje więcej niż 10 pkt w żadnym z następujących wskaźników: PASI, BSA i DLQI. \\ - Łuszczyca zwykła o nasileniu umiarkowanym do ciężkiego \\ Łuszczycę zwykłą o nasileniu umiarkowanym do ciężkiego rozpoznaje się, jeżeli przynajmniej w jednym ze wskaźników PASI, BSA lub DLQI pacjent uzyskał co najmniej 10 pkt. \\ - Pacjenci z łuszczycą łagodną często wymaga- ją jedynie leczenia miejscowego, ewentualnie połączonego z fototerapią. Wyjątek mogą sta- nowić m.in. pacjenci ze zmianami w tzw. loka- lizacjach szczególnych (paznokcie, skóra gło- wy, okolica anogenitalna). Pacjenci z łuszczycą umiarkowaną do ciężkiej powinni być leczeni fototerapią lub lekami ogólnymi, z wyjątkiem sytuacji, w których pacjent nie wyraża zgody na takie leczenie lub też stwierdza się prze- ciwwskazania do podjęcia takiego leczenia.}

\section{MILD PSORIASIS VULGARIS}

\section{Skin psoriasis}

Psoriatic lesions of mild intensity are treated primarily with topical medications (table 2). In cases with a large number of psoriatic lesions topical therapy can be supplemented with phototherapy. Topical drugs should also be used to treat "residual" psoriatic lesions persisting after systemic therapy. The most commonly used topical drugs include calcipotriol in combination with betamethasone, dithranol and glucocorticosteroids. Other agents used in the topical treatment of psoriasis include vitamin A derivates (tazarotene), calcineurin inhibitors and tars (table 2). A point to note is that keratolytic preparations (topical drugs containing urea, salicylic acid, lactic acid and/or sulphur) are often indicated at the beginning of psoriasis treatment in order to remove scale deposits covering psoriatic lesions which hinder the penetration of antipsoriatic drugs into lesions and may thus reduce the efficacy of topical treatment. Emollients can also be used as an adjunctive measure during topical therapy of psoriasis, based on their ability to reduce desquamation and itch, and general contribution to achieving better therapeutic effects.

\section{ŁUSZCZYCA ZWYKŁA O NASILENIU ŁAGODNYM}

\section{Łuszczyca skóry gładkiej}

W leczeniu zmian łuszczycowych o niewielkim nasileniu zastosowanie znajdują przede wszystkim leki miejscowe (tab. 2). W przypadku większej liczby ognisk chorobowych terapia miejscowa może być wsparta fototerapią. Leki miejscowe powinny być także stosowane w przypadku „resztkowych” zmian łuszczycowych po leczeniu ogólnym. Do najczęściej stosowanych preparatów miejscowych należą kalcypotriol w połączeniu z betametazonem, cygnolina oraz glikokortykosteroidy. W terapii miejscowej łuszczycy stosuje się także pochodne witaminy A (tazaroten), inhibitory kalcyneuryny oraz dziegcie (tab. 2). Warto podkreślić, że na początku leczenia zmian łuszczycowych często wskazane jest zastosowanie preparatów keratolitycznych (preparaty miejscowe zawierające mocznik, kwas salicylowy, kwas mlekowy i/lub siarkę) w celu usunięcia nawarstwień łusek pokrywających zmiany łuszczycowe, które utrudniają przenikanie leków przeciwłuszczycowych w głąb zmian chorobowych i mogą się przyczyniać do zmniejszenia skuteczności leczenia miejscowego. W trakcie miejscowej terapii łuszczycy może być także pomocne wspomagające stosowanie emolientów, które zmniejszają 
Table 2. Topical drugs for the treatment of plaque psoriasis

\begin{tabular}{|c|c|}
\hline Topical drug & Main effects \\
\hline Keratolytic preparations & $\begin{array}{l}\text { - Exfoliation of scale covering psoriatic lesions } \\
\text { - Low efficacy in monotherapy (effective only in combination with other therapeutic modalities) } \\
\text { - Possibility of combining with other therapeutic modalities, e.g. glucocorticosteroids } \\
\text { - Risk of toxicity associated with application to large body areas (salicylic acid) }\end{array}$ \\
\hline $\begin{array}{l}\text { Combination drug: calcipotriol/ } \\
\text { betamethasone dipropionate }\end{array}$ & $\begin{array}{l}\text { - High therapeutic efficacy and rapid onset of action } \\
\text { - Good tolerance and favourable cosmetic properties } \\
\text { - Application to not more than } 30 \% \text { of body surface area }\end{array}$ \\
\hline Dithranol & $\begin{array}{l}\text { - Good efficacy in monotherapy } \\
\text { - Possibility of application to large body areas } \\
\text { - Available mainly in the form of compounded drugs } \\
\text { - Risk of skin irritation } \\
\text { - Poor cosmetic properties (staining of clothes, skin hyperpigmentation) }\end{array}$ \\
\hline Tars & $\begin{array}{l}\text { - Relatively good efficacy in monotherapy } \\
\text { - Possible application to large body areas } \\
\text { - Potential carcinogenic effect } \\
\text { - Poor cosmetic properties (unpleasant odour, staining of clothes) }\end{array}$ \\
\hline Topical glucocorticosteroids & $\begin{array}{l}\text { - Rapid onset of action and good efficacy } \\
\text { - Good cosmetic properties } \\
\text { - Risk of persistent adverse effects (e.g. skin atrophy) associated with longer use } \\
\text { - No long-term therapeutic effect } \\
\text { - Tachyphylaxis associated with uninterrupted long-term therapy }\end{array}$ \\
\hline Vitamin $\mathrm{D}_{3}$ derivatives (tacalcitol) & $\begin{array}{l}\text { - Good efficacy } \\
\text { - Relatively well-tolerated (low risk of skin irritation) } \\
\text { - Good cosmetic properties } \\
\text { - Late onset of action (usually after 6-8 weeks) }\end{array}$ \\
\hline Retinoids (tazarotene) & $\begin{array}{l}\text { - Good cosmetic properties } \\
\text { - Efficacy of treatment demonstrated in controlled trials } \\
\text { - Risk of skin irritation }\end{array}$ \\
\hline $\begin{array}{l}\text { Calcineurin inhibitors } \\
\text { (pimecrolimus, tacrolimus) }\end{array}$ & $\begin{array}{l}\text { - Good cosmetic properties and favourable safety profile } \\
\text { - Effective only in some types of psoriasis vulgaris (facial psoriasis, inverse psoriasis) } \\
\text { - Risk of skin irritation particularly at the beginning of therapy } \\
\text { - Not approved for the treatment of psoriasis }\end{array}$ \\
\hline
\end{tabular}

The most widely used topical agents include calcipotriol in combination with betamethasone, mainly because of their synergistic effect against psoriasis, high efficacy, rapid onset of action and low risk of irritation. It is worth noting that calcipotriol has a capacity to reverse, at least partially, the atrophogenic effect of glucocorticosteroids [16]. According to the literature combination therapy with calcipotriol and betamethasone dipropionate is the most effective topical treatment modality in psoriasis [3]. The combination of calcipotriol and betamethasone is available in gel base, as ointment and recently also foam, however the latter galenic form is used quite rarely in Poland because of high cost and lack of reimbursement. Another derivative of vitamin $\mathrm{D}_{3}$ available on the Polish pharmaceutical market (tacalcitol) demonstrates efficacy verified in clinical trials, as well as good cosmetic properties and a favourable safety profile. Drawbacks of the drug is delayed onset of action (as a rule, full therapeutic effect is not achieved until 6-8 weeks after the initiation of treatment). Vitamin $\mathrm{D}_{3}$ analogues should be used with caution in patients nasilenie łuszczenia, świądu oraz ogólnie przyczyniają się do lepszych wyników terapeutycznych.

W terapii miejscowej najszerzej stosuje się kalcypotriol w połączeniu z betametazonem, głównie ze względu na synergizm działania przeciwłuszczycowego, dużą skuteczność, szybki początek działania i małe ryzyko podrażnień. Warto podkreślić, że kalcypotriol może przynajmniej częściowo odwracać atrofogenne działanie glikokortykosteroidu [16]. Według danych z piśmiennictwa połączenie kalcypotriolu $\mathrm{z}$ dipropionianem betametazonu jest najskuteczniejszą opcją leczenia miejscowego łuszczycy [3]. Połączenie kalcypotriolu z betametazonem dostępne jest w podłożu żelowym, maściowym, a ostatnio także $\mathrm{w}$ formie piany, choć ta ostatnia postać galenowa z powodu wyższej ceny i braku refundacji w Polce jest raczej rzadko stosowana. Dostępna na polskim rynku farmaceutycznym inna pochodna witaminy $\mathrm{D}_{3}$ (takalcytol) cechuje się skutecznością potwierdzoną w badaniach klinicznych, dobrymi właściwościami kosmetycznymi i korzystnym profilem bezpieczeństwa. Wadą leku jest opóźniony początek działania (z reguły pełny efekt terapeutyczny obserwuje się dopiero po 6-8 
Tabela 2. Leki do stosowania miejscowego w łuszczycy plackowatej

\begin{tabular}{|c|c|}
\hline Lek miejscowy & Główne cechy \\
\hline preparaty keratolityczne & $\begin{array}{l}\text { - } \text { działają złuszczająco na łuskę pokrywającą zmiany łuszczycowe } \\
\text { - cechują się słabą skutecznością w monoterapii (skuteczne jedynie w połączeniu z innymi } \\
\text { - metodami leczenia) } \\
\text { - mogą być łączone z innymi metodami terapii, np. preparatami glikokortykosteroidowymi } \\
\text { - } \text { możliwe zatrucia przy aplikacji na duże powierzchnie ciała (kwas salicylowy) }\end{array}$ \\
\hline $\begin{array}{l}\text { preparat złożony: kalcypotriol/ } \\
\text { dipropionian betametazonu }\end{array}$ & $\begin{array}{l}\text { - cechuje się dużą skutecznością i szybkim początkiem działania } \\
\text { - jest dobrze tolerowany i ma korzystne własności kosmetyczne } \\
\text { - może być aplikowany na maks. 30\% powierzchni skóry }\end{array}$ \\
\hline cygnolina & $\begin{array}{l}\text { - } \text { cechuje sie dobrą skutecznością w monoterapii } \\
\text { - może być aplikowana na dużą powierzchnię skóry } \\
\text { - dostępna gtównie w ramach leków recepturowych } \\
\text { - może powodować podrażnienia skóry } \\
\text { - ma słabe własności kosmetyczne (brudzi odzież, przebarwia skórę) }\end{array}$ \\
\hline dziegcie & $\begin{array}{l}\text { - charakteryzują się dość dobrą skutecznością w monoterapii } \\
\text { - mogą być aplikowane na dużą powierzchnię skóry } \\
\text { - mogą mieć działanie kancerogenne } \\
\text { - mają słabe własności kosmetyczne (niemily zapach, brudzenie odzieży) }\end{array}$ \\
\hline miejscowe glikokortykosteroidy & $\begin{array}{l}\text { - } \text { cechują się szybkim początkiem działania i dobrą skutecznością } \\
\text { - mają dobre własności kosmetyczne } \\
\text { - dłużej trwające stosowanie obarczone jest ryzykiem wystąpienia trwałych } \\
\text { - działań niepożądanych (m.in. atrofii skóry) } \\
\text { - } \text { nie powodują długotrwałego efektu leczniczego }\end{array}$ \\
\hline pochodne witaminy $D_{3}$ (takalcytol) & $\begin{array}{l}\text { - charakteryzują się dobrą skutecznością } \\
\text { - są względnie dobrze tolerowane (niewielkie ryzyko podrażnień skóry) } \\
\text { - mają dobre własności kosmetyczne } \\
\text { - cechują się późnym początkiem działania (zwykle po 6-8 tygodniach) }\end{array}$ \\
\hline retinoidy (tazaroten) & $\begin{array}{l}\text { - mają dobre własności kosmetyczne } \\
\text { - skuteczność terapii została potwierdzona w badaniach kontrolowanych } \\
\text { - mogą powodować podrażnienia skóry }\end{array}$ \\
\hline $\begin{array}{l}\text { inhibitory kalcyneuryny } \\
\text { (pimekrolimus, takrolimus) }\end{array}$ & $\begin{array}{l}\text { - mają dobre własności kosmetyczne i cechują się korzystnym profilem bezpieczeństwa } \\
\text { - są skuteczne jedynie w niektórych odmianach łuszczycy zwyczajnej } \\
\text { (łuszczyca twarzy, łuszczyca odwrócona) } \\
\text { - mogą podrażniać skórę, zwłaszcza na początku stosowania } \\
\text { - nie są zarejestrowane w leczeniu łuszczycy }\end{array}$ \\
\hline
\end{tabular}

with disorders of calcium and phosphate metabolism, liver or kidney failure, and in breast-feeding women. Vitamin $\mathrm{D}_{3}$ derivatives should not be combined with keratolytic preparations containing salicylic or lactic acids, as both calcipotriol and tacalcitol undergo neutralization in an acidic environment. In patients receiving combination treatment with vitamin $D_{3}$ derivatives and phototherapy, UV irradiation should be performed first, followed by the application of a topical drug (in such cases, a vitamin $\mathrm{D}_{3}$ derivative should preferably be used in the evening).

Dithranol is usually used in the hospital setting at increasing concentrations from $0.01 \%$ to $2-3 \%$ twice a day for 2-4 h (at lower concentrations the drug may be applied for a longer time). If higher drug concentrations (0.5-3\%) are used on an outpatient basis, the so-called "minutes therapy" can be used, with the drug administered at a high concentration from the beginning, but for a much shorter period (approximately 10-30 min). The mechanism of action tygodniach leczenia). Analogi witaminy $\mathrm{D}_{3}$ należy stosować ostrożnie u pacjentów z zaburzeniami gospodarki wapniowo-fosforanowej, $\mathrm{z}$ niewydolnością wątroby lub nerek oraz u kobiet karmiących piersią. Pochodnych witaminy $\mathrm{D}_{3}$ nie należy łączyć z preparatami keratolitycznymi zawierającymi kwas salicylowy lub mlekowy, gdyż zarówno kalcypotriol, jak i takalcytol ulegają unieczynnieniu w środowisku kwaśnym. W razie łącznego stosowania pochodnych witaminy $\mathrm{D}_{3} \mathrm{i}$ fototerapii należy najpierw wykonać zabieg naświetlania UV, a dopiero później aplikować preparat miejscowy (najlepiej zastosować pochodną witaminy $\mathrm{D}_{3}$ wieczorem).

Cygnolina jest zazwyczaj stosowana w warunkach szpitalnych we wzrastających stężeniach od 0,01\% do 2-3\% dwukrotnie w ciągu dnia przez 2-4 godziny (mniejsze stężenia mogą być pozostawiane na dłużej). W przypadku aplikowania wyższych stężeń leku (0,53\%) w warunkach ambulatoryjnych można zastosować tzw. terapię minutową, w przypadku której lek stosuje się od początku w dużym stężeniu, ale na znacznie krótszy 
of dithranol has not been fully explained, however the drug has a disease-limiting effect by inhibiting excessive proliferation of keratinocytes. A significant benefit of the drug is its ability to induce disease remission of many months' duration in a proportion of patients [17]. Disadvantages of dithranol include its poor cosmetic properties. The substance may cause skin hyperpigmentation and stain clothes. In addition, dithranol has a characteristic odour which is not always acceptable to patients. Also, dithranol has a potential to cause skin irritation and, for this reason, it may not be applied to skin folds, to the face (risk of conjunctival irritation and skin hyperpigmentations) and acutely inflamed lesions of plaque psoriasis.

Glucocorticosteroids are a widely used therapeutic option in the treatment of psoriatic skin lesions. Their benefits include rapid onset of action, high efficacy and good cosmetic properties. However, prolonged use of glucocorticosteroids on the skin is associated with a significant risk of persistent local complications including skin atrophy or telangiectasia. Moreover, the discontinuation of glucocorticosteroid therapy leads to rapid relapse of psoriatic lesions. In some patients, the rebound phenomenon occurs shortly after the withdrawal of a topical corticosteroid, manifested as the development of psoriatic lesions of higher severity than before the initiation of treatment. For this reason, topical glucocorticosteroids are only recommended for short-term therapy, and they are usually prescribed for initial treatment in order to achieve a more rapid remission of psoriatic lesions and in cases of disease exacerbation.

Tazarotene is currently the only topical retinoid approved in Poland for the treatment of plaque psoriasis. The drug is associated with a lower improvement rate compared to other topical antipsoriatic drugs, however following the regression of psoriatic lesions the duration of remission appears to be longer than after treatment with topical glucocorticosteroids or vitamin $\mathrm{D}_{3}$ derivatives [18]. As the drug has a propensity to cause skin irritation, it has the status of an alternative form of treatment which may be recommended in patients unsuccessfully treated with other topical medications or with small psoriatic lesions.

For a long time, tars (e.g. coal tar) were used in the topical treatment of psoriasis, producing good effects. However, on account of their potential carcinogenic effect demonstrated in vitro and in animal studies, the availability of the drugs has diminished and they are not currently recommended as primary therapy. Observational studies in humans have not found evidence for an increased risk of cancer development in patients with dermatological conditions treated with tars. In some patients, tars may be successfully used to complement other options of topical treatment [19]. czas (ok. 10-30 min). Mechanizm działania cygnoliny nie został dokładnie poznany, lek ma działanie redukujące hamuje nadmierną proliferację keratynocytów. Istotną zaletą cygnoliny jest możliwość uzyskania u części chorych wielomiesięcznych remisji choroby [17]. Wadą leku są złe własności kosmetyczne, gdyż może przebarwiać skórę i odzież, a także ma swoisty zapach, który nie zawsze jest akceptowany przez pacjentów. Ponadto cygnolina może powodować podrażnienia skóry i z tego powodu nie można jej stosować w okolice fałdów, na twarz (ryzyko podrażnień spojówek i przebarwień skóry) oraz w przypadku ostrozapalnych ognisk łuszczycy plackowatej.

Glikokortykosteroidy są szeroko stosowaną opcją terapeutyczną w leczeniu ognisk łuszczycy na skórze. Ich zaletami są szybkość działania, duża skuteczność i dobre właściwości kosmetyczne. Długotrwałe stosowanie glikokortykosteroidów na skórę wiąże się jednak $\mathrm{z}$ istotnym ryzykiem wystąpienia trwałych powikłań miejscowych, takich jak atrofia skóry lub teleangiektazje. Ponadto $\mathrm{w}$ chwili ich odstawienia często dochodzi do szybkiego nawrotu zmian łuszczycowych, a u części chorych obserwuje się zjawisko z odbicia, kiedy w krótkim czasie po zaprzestaniu aplikacji kortykosteroidu miejscowego dochodzi do wysiewu zmian łuszczycowych o większym nasileniu niż przed rozpoczęciem terapii. Z tego powodu kortykosteroidy miejscowe rekomenduje się tylko jako leczenie krótkotrwałe, zazwyczaj stosowane na początku terapii w celu uzyskania szybszego ustąpienia zmian łuszczycowych.

Tazaroten jest obecnie jedynym miejscowym retinoidem dopuszczonym w Polsce do stosowania w leczeniu łuszczycy plackowatej. Lek ten cechuje się mniejszym odsetkiem uzyskiwanej poprawy w porównaniu $\mathrm{z}$ innymi przeciwłuszczycowymi lekami miejscowymi, ale w chwili ustąpienia zmian łuszczycowych czas trwania remisji wydaje się dłuższy niż np. w przypadku miejscowych glikokortykosteroidów lub pochodnych witaminy $\mathrm{D}_{3}[18]$. Możliwość wywoływania podrażnień skóry powoduje, że jest to raczej alternatywna forma leczenia, która może być zalecana w przypadku niepowodzenia terapii innymi lekami miejscowymi lub też w przypadku niewielkich ognisk łuszczycy.

W leczeniu miejscowym łuszczycy przez długi czas z dobrym efektem stosowane były dziegcie (np. prodermina). Ze względu na ich potencjalne działanie rakotwórcze, wykazane w badaniach in vitro i na zwierzętach, leki te stały się trudno dostępne i nie są obecnie rekomendowane jako terapia pierwszoplanowa. Wyniki badań obserwacyjnych u ludzi nie potwierdziły zwiększonego ryzyka rozwoju nowotworów u chorych leczonych dziegciami z powodu schorzeń dermatologicznych, a dla niektórych chorych mogą one stanowić cenne uzupełnienie innych opcji leczenia miejscowego [19].

W przypadku pojedynczych zmian łuszczycowych korzystne efekty może przynieść leczenie laserem ekscy- 
Patients with isolated psoriatic lesions may benefit from excimer laser therapy (wavelength $308 \mathrm{~nm}$ ) or pulsed dye laser therapy (wavelength $595 \mathrm{~nm}$ ), however given the high cost of equipment and long duration of treatments, the therapy is not widely used in Poland [20, 21]. Perhaps the future will see more widespread applications of blue-light emitting devices, which can be used by patients themselves in their home setting [22].

\section{Recommendation IV}

- The recommended treatment of mild psoriasis vulgaris of the skin is based on topical drugs including vitamin $\mathrm{D}_{3}$ derivatives in monotherapy or in combination with a glucocorticosteroid, as well as dithranol, tars and synthetic vitamin A derivatives.

- Keratolytic preparations are indicated at the beginning of psoriasis treatment in order to remove scale deposits covering the lesions.

\section{SCALP PSORIASIS}

The presence of hair which impairs the penetration of drugs into psoriatic lesions often makes scalp psoriasis a difficult therapeutic problem. Keratolytic drugs (mainly salicylic acid in oil base and urea) may be indicated at the beginning of treatment in order to remove accumulated scale. The next stage of treatment should be based on drugs eliminating psoriatic lesions. At present, a widely used and recommended therapeutic option available for the treatment of scalp psoriasis is a ready-made combination of calcipotriol and betamethasone dipropionate in gel base, demonstrating both good efficacy and favourable cosmetic properties [3]. There are studies documenting longterm (12-month) safety and efficacy of treatment of scalp psoriasis with a combination of calcipotriol and betamethasone dipropionate in gel base or in the form of foam [23].

Alternatively, scalp psoriasis can also be treated with topical glucocorticosteroids which are available in the form of solutions, shampoos and foams (table 3) [24]. Tar-based shampoos can be used as an add-on treatment. Another therapeutic option is the use of solutions containing dithranol (for example dithranol spirit), however patients should be cautioned that close attention must be paid to the application of such products, so that the drug does not spread beyond the scalp and get into the eyes (risk of conjunctival irritation) or drip onto the face and neck (risk of hyperpigmentation) [25]. Patients with severe scalp lesions who fail to benefit from a properly conducted topical therapeutic regimen should be treated systemically. merowym o długości fali $308 \mathrm{~nm}$ lub pulsacyjnym laserem barwnikowym o długości fali 595 nm, ale ze względu na wysoki koszt urządzeń i czasochłonność zabiegów nie jest to terapia szeroko stosowana w Polsce [20, 21]. Być może większe zastosowanie w przyszłości znajdą urządzenia emitujące niebieskie światło, które mogą być samodzielnie stosowane przez pacjentów w warunkach domowych [22].

\section{Zalecenia IV}

- W leczeniu łagodnej łuszczycy zwykłej skóry gładkiej zaleca się stosowanie preparatów miejscowych, $\mathrm{w}$ tym pochodnych witaminy $\mathrm{D}_{3}$ $\mathrm{w}$ monoterapii lub $\mathrm{w}$ połączeniu $\mathrm{z}$ glikokortykosteroidem, a także cygnoliny, dziegci i syntetycznych pochodnych witaminy A.

- Na początku leczenia zmian łuszczycowych wskazane jest zastosowanie preparatów keratolitycznych w celu usunięcia nawarstwień łusek pokrywających zmiany.

\section{ŁUSZCZYCA SKÓRY OWŁOSIONEJ GŁOWY}

Łuszczyca skóry owłosionej głowy często stanowi trudny problem terapeutyczny ze względu na włosy, które utrudniają przenikanie leków do zmian łuszczycowych. Na początku terapii mogą być wskazane leki keratolityczne (przede wszystkim kwas salicylowy w podłożu olejowym oraz mocznik) w celu usunięcia nawarstwień łuski. W dalszym etapie konieczne jest stosowanie leków powodujących ustępowanie ognisk łuszczycy. Obecnie szeroko stosowaną i rekomendowaną opcją terapeutyczną w łuszczycy skóry owłosionej głowy jest połączenie kalcypotriolu z dipropionianem betametazonu w podłożu żelowym, które cechuje się dobrą skutecznością i korzystnymi właściwościami kosmetycznymi [3]. Dostępne są badania potwierdzające długoterminowe (12-miesięczne) bezpieczeństwo i skuteczność terapii łuszczycy skóry owłosionej głowy połączeniem kalcypotriolu z dipropionianem betametazonu w podłożu żelowym lub w formie piany [23].

Alternatywnie w terapii łuszczycy skóry owłosionej głowy można stosować glikokortykosteroidy miejscowe, które są dostępne w postaci roztworów, szamponów, a także w piankach (tab. 3) [24]. Wspomagająco mogą działać szampony z dziegciami. Można także aplikować roztwory zawierające cygnolinę (np. spirytus cygnolinowy), ale zawsze należy przestrzec pacjenta, aby w trakcie stosowania tych preparatów zwracał szczególną uwage, żeby lek nie spływał poza granice skóry owłosionej głowy i nie dostał się do oczu (podrażnienie spojówek) ani nie ściekał na twarz i szyję (ryzyko przebarwień) [25]. W przypadku nasilonych zmian w obrębie skóry owłosionej głowy, przy braku efektu prawidłowo prowadzonego 
Table 3. Topical treatment of scalp psoriasis

\begin{tabular}{ll}
\multicolumn{1}{c}{ Recommended treatment } & \multicolumn{1}{c}{ Alternative treatment } \\
- Combination of calcipotriol with betamethasone dipropionate & - Tars in the form of shampoos and solutions \\
in gel base or foam & - Dithranol spirit \\
- Medium- and high-potency topical glucocorticosteroids & - Tazarotene gel \\
$\begin{array}{l}\text { (in monotherapy or in combination with keratolytic } \\
\text { medications) in the form of solutions, shampoos and foams }\end{array}$ & \\
\hline
\end{tabular}

Tabela 3. Miejscowe leczenie łuszczycy owłosionej skóry głowy

\begin{tabular}{ll}
\multicolumn{2}{c}{ Leczenie rekomendowane } \\
- połączenie kalcypotriolu z dipropionianem betametazonu & • dziegcie w postaci szamponów i roztworów \\
w podłożu żelowym lub pianie & • spirytus cygnolinowy \\
- glikokortykosteroidy miejscowe o średniej i dużej sile działania & • tazaroten w żelu \\
(w monoterapii lub w połączeniu z lekami keratolitycznymi) & \\
w postaci roztworów, szamponów oraz pianek & \\
\hline
\end{tabular}

The above recommendation applies in particular to patients with moderate to severe scalp psoriasis. Scalp psoriasis is defined as moderate to severe if lesions involve more than $30 \%$ of the scalp surface, and one of the below criteria is met: the Physicians Global Assessment (PGA) score is over 3 (on a scale from 0 to 5) or the PASI score for the scalp is over 4.

It must be stressed that there have not been clinical trials evaluating the efficacy of the so-called classic systemic drugs (cyclosporin A, methotrexate, acitretin) in the treatment of scalp psoriasis. Consequently, such treatment is based exclusively on isolated literature data, previous experience and expert recommendations. Treatment with these drugs should be based on doses similar to those applied in the treatment of moderate to severe psoriasis.

Therapy with antipsoriatic biological drugs and new low-molecular weight compounds with antipsoriatic effects successfully reduces the severity of psoriatic lesions on the scalp, however the high cost of treatment markedly reduces their application [26]. Also, some new drugs have already been approved or are pending approval for the indication of moderate to severe scalp psoriasis. In 2018 secukinumab was approved in the USA for the treatment of isolated moderate to severe scalp psoriasis.

\section{FACIAL PSORIASIS}

From the perspective of patients, psoriatic lesions located on the face are a particularly challenging health problem, as they affect a body part that is difficult to hide. It is for this reason that facial psoriasis is associated with a considerable degree of discomfort and stigma. It appears that the main topical drugs for application to facial skin should be calcineurin inhibitors (particularly tacrolimus) because of their good cosmetic properties and safety of long-term therapy. Even though tacrolimus and pimecrolimus are approved leczenia miejscowego, zaleca się podjęcie leczenia ogólnego. Dotyczy to zwłaszcza pacjentów z umiarkowaną do ciężkiej łuszczycą skóry owłosionej głowy. Łuszczyca skóry owłosionej głowy jest definiowana jako umiarkowana do ciężkiej, gdy zajęte jest ponad 30\% powierzchni skóry głowy oraz spełnione jest jedno z następujących warunków: Physicians Global Assessment (PGA) wynosi powyżej 3 (w skali 0-5) lub PASI dla skóry głowy wynosi powyżej 4.

Należy podkreślić, że brakuje badań klinicznych oceniających skuteczność tzw. klasycznych leków ogólnych (cyklosporyny A, metotreksatu, acytretyny) w leczeniu łuszczycy w tej okolicy i taka terapia opiera się wyłącznie na pojedynczych danych z piśmiennictwa oraz doświadczeniu i rekomendacjach eksperckich. W przypadku stosowania tych leków zaleca się dawki porównywalne ze stosowanymi w leczeniu łuszczycy umiarkowanej do ciężkiej.

Wykazano, że terapia zarówno przeciwłuszczycowymi lekami biologicznymi, jak i nowymi substancjami drobnocząsteczkowymi o działaniu przeciwłuszczycowym skutecznie redukuje nasilenie zmian łuszczycowych w obrębie skóry owłosionej głowy, jednak wysoki koszt znacząco ogranicza jej stosowanie [26]. W przypadku niektórych nowych leków łuszczyca skóry owłosionej głowy umiarkowana do ciężkiej jest wskazaniem rejestracyjnym lub jest w okresie rejestracji. W 2018 r. sekukinumab został zarejestrowany w USA do leczenia izolowanej umiarkowanej do ciężkiej łuszczycy skóry owłosionej głowy.

\section{ŁUSZCZYCA TWARZY}

Zmiany łuszczycowe na twarzy stanowią szczególnie istotny problem zdrowotny z punktu widzenia pacjenta, gdyż znajdują się w okolicy, którą jest trudno ukryć. $Z$ tego powodu łuszczyca twarzy wywołuje znacznego stopnia dyskomfort i poczucie piętna. Wydaje się, że podstawowymi preparatami miejscowymi do stosowania na skórę twarzy powinny być inhibitory kalcyneuryny (zwłaszcza takrolimus) ze względu na dobre właściwości kosmetyczne i bezpieczeństwo terapii długoterminowej. 
Table 4. Topical treatment of facial psoriasis

\begin{tabular}{ll}
\multicolumn{1}{c}{ Recommended treatment } & \multicolumn{1}{c}{ Alternative treatment } \\
- Topical calcineurin inhibitors (tacrolimus, less commonly & $\bullet$ Vitamin A derivatives (tazarotene) \\
pimecrolimus) & $\bullet$ Vitamin $D_{3}$ derivatives \\
- Low- and medium-potency topical glucocorticosteroids & \\
(short-term treatment) & \\
\hline
\end{tabular}

Tabela 4. Miejscowe leczenie łuszczycy twarzy

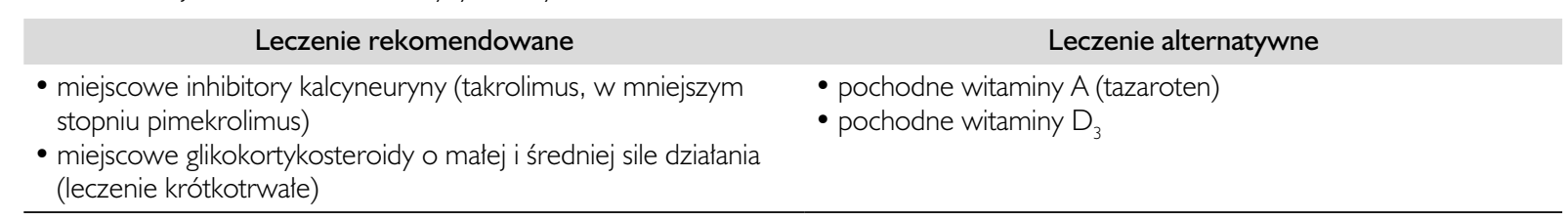

only for the therapy of atopic dermatitis, they have documented efficacy in the treatment of facial psoriasis $[27,28]$. The use of the two drugs in psoriasis, however, is not consistent with the summary of product characteristics, which must be communicated to the patient before the start of treatment. Patients with severe lesions may benefit from the application of low - and mediumpotency topical glucocorticosteroids to the skin of the face for short periods [3]. If the treatment is unsuccessful, alternative therapeutic modalities include vitamin A derivatives (tazarotene) and possibly also vitamin $\mathrm{D}_{3}$ derivatives (tacalcitol), however there are currently no data confirming their safety and therapeutic efficacy in this form of psoriasis (table 4).

\section{INVERSE PSORIASIS}

In some patients psoriatic lesions may involve atypical sites including flexor surfaces and skin folds (most commonly the axilla and groins, intergluteal cleft or inframammary folds). This form of psoriasis is referred to as "inverse psoriasis". Skin lesions are smooth and shiny, without scales accompanying other types of psoriasis. As a result, in some cases of the disease the diagnosis can only be made on the basis of histological examination.

The main drugs recommended for treatment of inverse psoriasis include low - and medium-potency topical glucocorticosteroids either in monotherapy or in combination with an antibiotic or antifungal agent, and calcineurin inhibitors (as in facial psoriasis, the use of calcineurin inhibitors in this indication would be off-label) [28]. An alternative therapeutic modality is the cautious application of vitamin A and vitamin $D_{3}$ derivatives, though it should be remembered that both drug groups may induce local irritation reactions (table 5). Anthralin or tar preparations should not be applied to skin folds or flexor surfaces because they may induce severe skin irritation in these areas.
Takrolimus i pimekrolimus są zarejestrowane jedynie do stosowania w atopowym zapaleniu skóry, jednak te leki cechują się udokumentowaną skutecznością w leczeniu łuszczycy twarzy [27, 28]. Ich stosowanie w łuszczycy nie jest jednak zgodne $\mathrm{z}$ charakterystyką produktu leczniczego, o czym należy poinformować pacjenta przed rozpoczęciem leczenia. W przypadku zmian o dużym nasileniu mogą być krótkotrwale stosowane na twarz miejscowe glikokortykosteroidy o małej i średniej sile działania [3]. W przypadku niepowodzenia terapii alternatywą są pochodne witaminy A (tazaroten) oraz ewentualnie pochodne witaminy $\mathrm{D}_{3}$ (takalcytol), choć obecnie nie ma danych potwierdzających ich bezpieczeństwo i skuteczność w tej postaci łuszczycy (tab. 4).

\section{ŁUSZCZYCA ODWRÓCONA}

U niektórych pacjentów zmiany łuszczycowe mogą nietypowo występować w okolicy zgięć stawowych i w fałdach skórnych (najczęściej w dołach pachowych, pachwinach, szparze pośladkowej lub w fałdach podsutkowych). Dla tej postaci łuszczycy stosuje się określenie „łuszczyca odwrócona”. Ogniska chorobowe z reguły są gładkie, połyskujące, pozbawione typowej dla łuszczycy łuski. Z tego powodu niektóre przypadki choroby możliwe są do rozpoznania jedynie na podstawie badania histologicznego.

W leczeniu łuszczycy odwróconej zaleca się głównie glikokortykosteroidy miejscowe o małej i średniej sile działania w monoterapii lub w połączeniu z antybiotykiem i środkiem przeciwgrzybiczym oraz inhibitory kalcyneuryny (podobnie jak w łuszczycy twarzy jest to stosowanie inhibitorów kalcyneuryny poza wskazaniami rejestracyjnymi) [28]. Alternatywnie można zalecać ostrożną aplikację pochodnych witaminy A i pochodnych witaminy $\mathrm{D}_{3^{\prime}}$ choć należy pamiętać, że obie grupy leków mogą powodować miejscowe odczyny podrażnieniowe (tab. 5). W okolice fałdów lub zgięć stawowych nie należy natomiast stosować preparatów cygnoliny i dziegci ze względu na możliwość ciężkiego podrażnienia skóry. 
Table 5. Topical therapy of inverse psoriasis

\begin{tabular}{|c|c|}
\hline Recommended treatment & Alternative treatment \\
\hline $\begin{array}{l}\text { - Low- and medium-potency topical glucocorticosteroids } \\
\text { (short-term treatment) in monotherapy or in combination with } \\
\text { antibiotic or antifungal agent } \\
\text { - Calcineurin inhibitors (tacrolimus, pimecrolimus) }\end{array}$ & $\begin{array}{l}\text { - Vitamin A derivatives (tazarotene) } \\
\text { - Vitamin } \mathrm{D}_{3} \text { derivatives }\end{array}$ \\
\hline
\end{tabular}

Tabela 5. Miejscowe leczenie łuszczycy odwróconej

\begin{tabular}{|c|c|}
\hline Leczenie rekomendowane & Leczenie alternatywne \\
\hline $\begin{array}{l}\text { - glikokortykosteroidy miejscowe o małej i średniej sile działania } \\
\text { (leczenie krótkotrwałe) w monoterapii lub w połączeniu } \\
\text { z antybiotykiem i lekiem przeciwgrzybiczym } \\
\text { - inhibitory kalcyneuryny (takrolimus, pimekrolimus) }\end{array}$ & $\begin{array}{l}\text { - pochodne witaminy } A \text { (tazaroten) } \\
\text { - pochodne witaminy } D_{3}\end{array}$ \\
\hline
\end{tabular}

\section{PALMOPLANTAR PSORIASIS}

Psoriatic lesions on the hands and feet may accompany psoriasis in a different location, but they may also be the only manifestation of the disease. Palmoplantar psoriasis is characterized by a chronic course and it is considerably more refractory to antipsoriatic treatment than psoriatic lesions in other locations, representing a major health problem for patients. Lesions affecting the hands often reduce or completely impair the ability to perform work or activities of daily living, whereas lesions on the feet, which are accompanied by cracks, fissures and pain, cause severe difficulties while walking. Since palmoplantar psoriasis is associated with marked impairment in patient functioning, systemic treatment is more commonly initiated in this group than in patients with other forms of mild psoriasis - even if the disease severity criteria required for the diagnosis of moderate to severe psoriasis are not met.

The difficulty of treating palmoplantar psoriasis is related to the fact that these body sites have a thicker stratum corneum, which impairs the penetration of topical medications into the skin. The initial therapeutic modality in palmoplantar psoriasis should be topical therapy, possibly in combination with topical phototherapy or excimer laser treatment (table 6) [3]. Occlusive dressings can be used to increase the penetration of topical medications. Often keratolytic drugs are used at the start of therapy and followed by the main part of psoriasis treatment. Combination drugs containing potent glucocorticosteroids and keratolytic agents may be useful. In addition to glucocorticosteroids, the efficacy of vitamin $\mathrm{D}_{3}$ derivatives and tars has also been reported (table 6) [3].

If topical treatment fails, systemic therapy should be considered in patients with palmoplantar psoriasis, particularly if their quality of life is markedly impaired. Improvement has been observed after treatment with cyclosporin A, methotrexate, acitretin and a range of biological drugs. It must be noted that patients treated with some biologics have been

\section{ŁUSZCZYCA RAK I STÓP}

Zmiany łuszczycowe na rękach i stopach mogą towarzyszyć łuszczycy o innej lokalizacji, ale mogą być też jedyną manifestacją choroby. Łuszczyca rąk i stóp charakteryzuje się przewlekłym przebiegiem, znacznie większą opornością na stosowane leczenie przeciwłuszczycowe w porównaniu ze zmianami łuszczycowymi w innej lokalizacji oraz stanowi istotny problem zdrowotny dla pacjentów. Zmiany na rękach nierzadko utrudniają, a czasami wręcz uniemożliwiają wykonywanie pracy zawodowej oraz codziennych obowiązków. Z kolei zmiany na stopach ze względu na pojawiające się pęknięcia i rozpadliny oraz towarzyszący im ból stanowią poważne utrudnienie przy chodzeniu. Znaczne upośledzenie funkcjonowania pacjentów z łuszczycą rąk i stóp powoduje, że chętniej niż w innych postaciach łuszczycy łagodnej sięga się u nich po leczenie ogólne, nawet jeśli nie zostają spełnione kryteria ciężkości choroby upoważniające do rozpoznania łuszczycy umiarkowanej do ciężkiej.

Trudność leczenia łuszczycy rąk i stóp wynika ze znacznie grubszej warstwy rogowej naskórka w tych okolicach, a także gorszej penetracji leków miejscowych w głąb skóry. Leczenie łuszczycy rąk i stóp należy rozpocząć od terapii miejscowej, nierzadko w skojarzeniu $\mathrm{z}$ miejscową fototerapią lub laserem ekscymerowym (tab. 6) [3]. Aby zwiększyć przenikanie leków miejscowych, można wykorzystać opatrunki okluzyjne. Często na początku stosuje się leki keratolityczne, a dopiero później zasadniczą terapię przeciwłuszczycową. Pomocne może być aplikowanie preparatów łączonych, zawierających silne glikokortykosteroidy z lekami keratolitycznymi. Oprócz glikokortykosteroidów wskazywano także na skuteczność pochodnych witaminy $\mathrm{D}_{3}$ i dziegci (tab. 6) [3].

W przypadku niepowodzenia leczenia miejscowego należy rozważyć zasadność terapii ogólnej chorych na łuszczycę rąk i stóp, zwłaszcza w przypadku znacznego obniżenia jakości ich życia. Poprawę obserwowano po zastosowaniu cyklosporyny A, metotreksatu, acytretyny oraz wielu leków biologicznych. Należy zaznaczyć, że pojawienie się zmian o typie łuszczycy 
Table 6. Treatment of palmoplantar psoriasis

\begin{tabular}{|c|c|c|}
\hline $\begin{array}{l}\text { Topical treatment (attempt at topical } \\
\text { treatment is recommended) }\end{array}$ & Combination therapy & $\begin{array}{l}\text { Systemic treatment (indicated in cases } \\
\text { with very severe lesions not responding } \\
\text { to topical and/or combination treatment) }\end{array}$ \\
\hline $\begin{array}{l}\text { - Keratolytic medications (mainly at the } \\
\text { beginning of therapy) } \\
\text { - Potent glucocorticosteroids in } \\
\text { combination with keratolytic drugs } \\
\text { (if necessary, under occlusion) } \\
\text { - Vitamin } D_{3} \text { derivatives in combination } \\
\text { with potent glucocorticosteroids } \\
\text { (if necessary, under occlusion) } \\
\text { - Tars in combination with } \\
\text { glucocorticosteroids and keratolytic } \\
\text { medications }\end{array}$ & $\begin{array}{l}\text { - Topical PUVA therapy or UVB } 3 \text { I I } \\
\text { nm phototherapy in combination with } \\
\text { topical treatment } \\
\text { - Excimer laser treatment in combination } \\
\text { with topical therapy }\end{array}$ & $\begin{array}{l}\text { - Cyclosporin A } \\
\text { - Methotrexate } \\
\text { - Acitretin } \\
\text { - Dimethyl fumarate } \\
\text { - Biologics }\end{array}$ \\
\hline
\end{tabular}

Tabela 6. Leczenie łuszczycy rąk i stóp

\begin{tabular}{|c|c|c|}
\hline $\begin{array}{l}\text { Leczenie miejscowe (wskazane podjęcie } \\
\text { próby leczenia miejscowego) }\end{array}$ & Leczenie skojarzone & $\begin{array}{c}\text { Leczenie ogólne (wskazane przy dużym } \\
\text { nasileniu zmian i w razie niepowodzenia } \\
\text { leczenia miejscowego i/lub leczenia } \\
\text { skojarzonego) }\end{array}$ \\
\hline $\begin{array}{l}\text { - leki keratolityczne (głównie na początku } \\
\text { terapii) } \\
\text { - silne glikokortykosteroidy w połączeniu } \\
\text { z lekami keratolitycznymi (w razie potrzeby } \\
\text { w okluzji) } \\
\text { - pochodne witaminy } \mathrm{D}_{3} \text { w połączeniu } \\
\text { z silnymi glikokortykosteroidami (w razie } \\
\text { potrzeby w okluzji) } \\
\text { - dziegcie w połączeniu z glikokortyko- } \\
\text { steroidami i lekami keratolitycznymi }\end{array}$ & $\begin{array}{l}\text { - miejscowa PUVA-terapia lub } \\
\text { fototerapia UVB } 3 \text { I I nm w skojarze- } \\
\text { niu z leczeniem miejscowym } \\
\text { - laser ekscymerowy w skojarzeniu } \\
\text { z leczeniem miejscowym }\end{array}$ & $\begin{array}{l}\text { - cyklosporyna A } \\
\text { - metotreksat } \\
\text { - acytretyna } \\
\text { - dimetylan fumaranu } \\
\text { - leki biologiczne }\end{array}$ \\
\hline
\end{tabular}

shown to develop lesions typical of palmoplantar (particularly pustular) psoriasis. As a consequence, caution must be exercised when using these drugs in the therapy of palmoplantar psoriasis.

\section{TREATMENT OF NAIL PSORIASIS}

Effective treatment of nail lesions secondary to psoriasis presents a great challenge for dermatologists. The difficulty is due to problems with drug penetration into the the nail matrix and nail bed, and the long period required for the regrowth of healthy nail plate (usually ranging from 6 to 24 months). As a result, the prescribed drug should be used regularly on a long-term basis. Adherence to such a regimen may be difficult to achieve in many patients, especially if no clear improvement is observed in a short period. A potentially useful tool for the assessment of nail lesions and efficacy of treatment is Nail Psoriasis Severity Index (NAPSI) [29].

In the initial period of treatment, particularly in patients with less pronounced nail plate lesions, topical therapy should be attempted. Recommended medications include high - and ultra-high-potency glucocorticosteroids in combination with keratolytic drugs, vitamin A derivatives (tazarotene) and calcipotriol in rąk i stóp (zwłaszcza krostkowej) obserwowano u pacjentów leczonych niektórymi lekami biologicznymi i z tego powodu preparaty te powinny być stosowane z ostrożnością w łuszczycy rąk i stóp.

\section{LECZENIE ŁUSZCZYCY PAZNOKCI}

Skuteczna terapia zmian paznokciowych powstałych w przebiegu łuszczycy stanowi ogromne wyzwanie dla każdego dermatologa. Wynika to przede wszystkim z trudności w przenikaniu leku do macierzy i łożyska paznokcia oraz z długiego czasu, jaki jest potrzebny do odrostu zdrowej płytki paznokciowej (z reguły okres ten waha się od 6 do 24 miesięcy). Powoduje to konieczność długotrwałego i regularnego stosowania leku, co u wielu chorych, przy braku widocznej poprawy w krótkim czasie, może być trudne do uzyskania. W ocenie nasilenia zmian paznokciowych oraz skuteczności leczenia pomocny jest wskaźnik Nail Psoriasis Severity Index (NAPSI) [29].

W pierwszym okresie leczenia, zwłaszcza przy mniej nasilonych zmianach w obrębie płytek paznokciowych, powinno się podjąć próbę terapii miejscowej. Zastosowanie mają silne i bardzo silne glikokortykosteroidy w połączeniu z lekami keratolitycznymi, pochodne witaminy A (tazaroten) oraz połączenie kalcypotriolu z dipro- 
Table 7. Treatment of nail psoriasis

\begin{tabular}{cl}
$\begin{array}{c}\text { Topical treatment (attempt at topical treatment is } \\
\text { recommended for mild nail lesions, occlusive dressings } \\
\text { increase the penetration of topical drugs and contribute } \\
\text { to improving the efficacy of treatment) }\end{array}$ & \multicolumn{1}{c}{$\begin{array}{c}\text { Systemic treatment (indicated in severe } \\
\text { nail lesions and/or after failure of one } \\
\text { of the topical therapies listed above) }\end{array}$} \\
$\begin{array}{cl}\text { - Calcipotriol in combination with betamethasone dipropionate } \\
\text { - Potent glucocorticosteroids in combination with keratolytic }\end{array}$ & $\begin{array}{l}\text { - Biological drugs } \\
\text { medications }\end{array}$ \\
- Vitamin A derivatives (tazarotene) & $\begin{array}{l}\text { - Acitretin } \\
\text { - Cyclosporin A }\end{array}$ \\
\hline
\end{tabular}

Tabela 7. Leczenie łuszczycy paznokci

Leczenie miejscowe (wskazane podjęcie próby leczenia miejscowego przy zmianach paznokciowych o lagodnym nasileniu, opatrunek okluzyjny zwiększa penetrację leków miejscowych i przyczynia się do poprawy skuteczności leczenia)

- połączenie kalcypotriolu z dipropionianem betametazonu

- silne glikokortykosteroidy w połączeniu z lekami keratolitycznymi

- pochodne witaminy A (tazaroten)
Leczenie ogólnoustrojowe (wskazane przy dużym nasileniu zmian paznokciowych i/lub $w$ razie niepowodzenia jednej z wymieniowych powyżej metod terapii miejscowej)
- leki biologiczne

- metotreksat

- acytretyna

- cyklosporyna A combination with betamethasone dipropionate (table 7$)[30,31]$. The efficacy of topical treatment is assessed at $30-40 \%$. If topical treatment proves unsuccessful or skin lesions become more prominent (onycholysis with subungual hyperkeratosis or dystrophy involving $\geq 50 \%$ of the nail plate area, with at least three finger nail plates affected), the potential benefit of systemic treatment with one of the widely available systemic antipsoriatic drugs should be considered (table 7). Alternatively, the NAPSI score of 20 (on a scale from 1 to 160) may be used as a criterion for introducing systemic treatment. Systemic treatment (methotrexate, cyclosporin, acitretin, new low-molecular weight compounds with antipsoriatic effects, biological drugs) may be indicated even if the severity of other psoriatic lesions on the skin does not justify the diagnosis of moderate to severe psoriasis. Some authors also recommend intralesional injections (administered to the nailfold area) of glucocorticosteroids and methotrexate. At present, however, there are no reliable studies providing strong evidence on the efficacy and, above all, safety of this form of treatment compared to other (especially systemic) therapeutic modalities, whereas the treatment is very painful and, as a rule, must be performed under local anaesthesia or administered using a Dermojet device, which limits its widespread use. Biological treatment is the most effective mode of therapy for patients with nail psoriasis, and where the cost of therapy is not an issue, it is used as first-line systemic treatment.

\section{TREATMENT OF CHILDHOOD PSORIASIS}

The treatment of psoriasis in the paediatric population is essentially the same as in adults. Topical treatment should be used in patients with limited involve- pionianem betametazonu (tab. 7) [30, 31]. Skuteczność leczenia miejscowego ocenia się na ok. 30-40\%. Jeżeli terapia miejscowa okaże się nieskuteczna lub zmiany są bardziej nasilone (obecność onycholizy z podpaznokciową hiperkeratozą lub dystrofia obejmująca $\geq 50 \%$ powierzchni płytki w obrębie przynajmniej 3 płytek paznokciowych palców rąk) należy rozważyć celowość leczenia ogólnego jednym z dostępnych leków przeciwłuszczycowych (tab. 7). Alternatywnie jako kryterium włączenia leczenia ogólnego można przyjąć NAPSI o wartości 20 (w skali 1-160). Leczenie ogólne (metotreksat, cyklosporyna, acytretyna, nowe substancje drobnocząsteczkowe o działaniu przeciwłuszczycowym, leki biologiczne) może być wskazane nawet wtedy, gdy nasilenie pozostałych ognisk łuszczycy na skórze nie pozwala rozpoznać łuszczycy umiarkowanej do ciężkiej. Część autorów zaleca także doogniskowe (w okolicę wału paznokciowego) wstrzykiwanie glikokortykosteroidów lub metotreksatu. Obecnie brakuje jednak wiarygodnych badań potwierdzających skuteczność i przede wszystkim bezpieczeństwo tej formy leczenia w porównaniu z innymi (zwłaszcza ogólnymi) metodami terapii. Leczenie takie jest bardzo bolesne i z reguły musi być wykonywane w znieczuleniu miejscowym lub za pomocą dermojetu, co ogranicza jego powszechne stosowanie. Leczenie biologiczne jest najbardziej skuteczną metodą terapii łuszczycy paznokci i przy braku ograniczeń ekonomicznych stosowane jest jako pierwsza linia terapii ogólnej.

\section{LECZENIE ŁUSZCZYCY OKRESU DZIECIĘCEGO}

Terapia łuszczycy w populacji pediatrycznej nie odbiega zasadniczo od leczenia osób dorosłych. W przypadku ograniczonych zmian chorobowych (PASI 
ment (PASI score $<10$, BSA $<10 \%$ ), and phototherapy or systemic treatment should be added in patients with more severe lesions (PASI score $\geq 10$, BSA $\geq 10 \%$ ).

A key aspect that must be considered when discussing the topical treatment of childhood psoriasis is that certain drug groups (tazarotene, calcipotriol in combination with betamethasone dipropionate) are not approved for the therapy of patients under 18 years of age. As a result, their use should be limited to cases which fail to respond to other therapeutic modalities. Based on the available study results, the combination of calcipotriol with betamethasone dipropionate can be safely used in children at the age of 12 years and older, with the recommended duration of treatment being 4 weeks. A combination of the substances at a concentration of $0.005 \% / 0.064 \%$ (i.e. higher than in the product available in Poland) is currently approved in the USA for the treatment of scalp psoriasis in patients from 12 years of age.

Another aspect that must be considered in paediatric treatment is a significantly higher degree of systemic absorption of topical medications in children, and hence an increased risk of adverse reactions to topical drugs. Also, multiple adjacent skin folds present in children, and the use of diapers or diaper pants, may create occlusive conditions, additionally increasing the absorption of drugs from these body areas. As a consequence, treatment based, for example, on keratolytic preparations containing salicylic acid requires caution in view of the risk of toxic effects caused by excessive drug absorption through the skin.

Anthralin remains the gold standard in the topical treatment of psoriasis in children (table 2). Glucocorticosteroid drugs approved for the treatment of psoriasis in a particular age group can be used as an alternative. In cases of facial skin involvement calcineurin inhibitors are recommended (off-label use) because of their confirmed efficacy and good safety profile. Important aspects during treatment include appropriate skin care and moisturization with emollients.

In severe psoriasis topical therapy should be supplemented by systemic treatment. Systemic drugs used in the paediatric population include acitretin, cyclosporin A, methotrexate, and etanercept and adalimumab. As retinoid use in children is linked to bone growth disorders (premature epiphyseal closure in long bones), the body growth process must be closely monitored. The selection of an appropriate drug should be based on results of additional tests and possible comorbidities. Biological drugs should be recommended in childhood psoriasis if the patient has not adequately responded to at least one classical systemic therapeutic modality or cannot receive this type of treatment because of intolerance, side effects or comorbidities. Children can also be treated with UVB phototherapy (NB-UVB from the age
<10 pkt, BSA < 10\%) należy stosować terapię miejscową, natomiast $\mathrm{w}$ przypadku zmian bardziej nasilonych (PASI $\geq 10$ pkt, BSA $\geq 10 \%$ ) konieczne jest dołączenie fototerapii lub leczenia ogólnego.

Omawiając leczenie miejscowe łuszczycy wieku dziecięcego, należy zwrócić uwagę na to, że niektóre grupy leków (tazaroten, połączenie kalcypotriolu z dipropionianem betametazonu) nie są zarejestrowane do stosowania u osób poniżej 18. roku życia. Z tego powodu ich stosowanie powinno być ograniczone jedynie do przypadków nieodpowiadających na inne metody terapii. Dostępne wyniki badań pozwalają na stwierdzenie, że połączenie kalcypotriolu z dipropionianem betametazonu może być bezpiecznie stosowane przez dzieci od 12. roku życia, przy czym rekomendowany czas leczenia to 4 tygodnie. Połączenie tych substancji w stężeniu 0,005\%/0,064\% (czyli większym niż produkt dostępny w Polsce) jest obecnie zarejestrowane w USA do leczenia łuszczycy skóry głowy od 12. roku życia.

Kolejnymi odmiennościami leczenia pediatrycznego są zdecydowanie większy stopień wchłaniania do organizmu leków miejscowych oraz zwiększone ryzyko rozwoju działań niepożądanych po zastosowaniu leków miejscowych. Ponadto przyleganie fałdów skóry do siebie i stosowanie pieluch lub pieluchomajtek $u$ małych dzieci może się przyczyniać do okluzji, co dodatkowo zwiększa absorpcję leków z tych okolic ciała. Z tego powodu leczenie $\mathrm{z}$ wykorzystaniem np. preparatów keratolitycznych zawierających kwas salicylowy należy prowadzić z ostrożnością ze względu na możliwość działań toksycznych w wyniku nadmiernej absorpcji leku przez skórę.

Złotym standardem w terapii miejscowej łuszczycy u dzieci jest cygnolina (tab. 2). Alternatywnie można stosować preparaty glikokortykosteroidowe, które mają rejestrację w danej grupie wiekowej. W przypadku zajęcia skóry twarzy zaleca się inhibitory kalcyneuryny (leczenie poza wskazaniami rejestracyjnymi leku), które cechują się potwierdzoną skutecznością i dobrym profilem bezpieczeństwa. $W$ trakcie leczenia nie należy zapominać o właściwej pielęgnacji i o nawilżaniu skóry za pomocą emolientów.

W przypadku łuszczycy o dużym nasileniu wskazane jest dołączenie do terapii miejscowej leczenia ogólnego. Do leków ogólnych stosowanych u dzieci należą: acytretyna, cyklosporyna A, metotreksat, etanercept i adalimumab. Przy stosowaniu retinoidów u dzieci należy pamiętać o możliwości wystąpienia zaburzeń procesu kostnienia (przedwczesne zarastanie przynasad kości długich) i uważnie kontrolować proces wzrostu dziecka. Dobór odpowiedniego preparatu zależy od wyników badań dodatkowych i ewentualnych schorzeń współistniejących. Leki biologiczne w łuszczycy dziecięcej powinny być zalecane, jeśli pacjent nie odpowiedział zadowalająco na przynajmniej jedną klasyczną metodę terapii ogólnej bądź też nie może jej stosować z uwa- 
of 3-4 years). Photochemotherapy (PUVA) which is approved for the treatment of children over 12 years of age should be prescribed with a high degree of caution because of its potential procarcinogenic effects, and its use should be limited to situations when expected benefits outweigh possible adverse effects of treatment in a given patient. Phototherapy or photochemotherapy should not be combined with cyclosporin A.

\section{CONCLUSIONS}

We want to emphasize that in each case the physician in charge must adjust their diagnostic and therapeutic decisions to the current needs of the patient, taking into consideration the patient's present clinical status and referring to the most up-to-date medical knowledge.

\section{CONFLICT OF INTEREST}

The authors declare no conflict of interest. gi na brak tolerancji, objawy uboczne lub schorzenia współistniejące. U dzieci można także stosować fototerapię UVB (NB-UVB od 3.-4. roku życia). Fotochemoterapia (PUVA) dostępna dla dzieci powyżej 12. roku życia ze względu na możliwe działanie prokancerogenne powinna być zalecana z dużą ostrożnością, jedynie gdy ewentualne korzyści przeważają nad ewentualnymi niekorzystnymi następstwami takiego leczenia u chorego. Nie należy łączyć fototerapii lub fotochemoterapii z cyklosporyną A.

\section{PODSUMOWANIE}

Pragniemy zaznaczyć, że każdorazowo lekarz prowadzący leczenie musi dostosować swoje decyzje diagnostyczne i terapeutyczne indywidualnie do bieżących potrzeb chorego, uwzględniając jego aktualny stan kliniczny, a także opierając się na bieżących doniesieniach naukowych.

\section{KONFLIKT INTERESÓW}

Autorzy nie zgłaszają konfliktu interesów.

\section{References \\ Piśmiennictwo}

1. Michalek I.M., Loring B., John S.M.: A systematic review of worldwide epidemiology of psoriasis. J Eur Acad Dermatol Venereol 2017, 31, 205-212.

2. Szepietowski J., Adamski Z., Chodorowska G., Gliński W., Kaszuba A., Placek W., et al.: Rekomendacje Polskiego Towarzystwa Dermatologicznego dotyczące stosowania leków biologicznych w łuszczycy zwyczajnej i stawowej (łuszczycowym zapaleniu stawów). Przegląd Dermatol 2010, 97, 1-13.

3. Szepietowski J., Adamski Z., Chodorowska G., Gliński W., Kaszuba A., Placek W., et al.: Leczenie łuszczycy zwyczajnej - rekomendacje ekspertów Polskiego Towarzystwa Dermatologicznego. Część I: łuszczyca łagodna, łuszczyca wieku dziecięcego. Przegl Dermatol 2012, 99, 83-96.

4. Szepietowski J., Adamski Z., Chodorowska G., Kaszuba A., Placek W., Rudnicka L., et al.: Leczenie łuszczycy - rekomendacje ekspertów Polskiego Towarzystwa Dermatologicznego. Część II: łuszczyca umiarkowana do ciężkiej. Przegl Dermatol 2014, 101, 455-472.

5. Radtke M.A., Reich K., Blome C., Rustenbach S., Augustin M.: Prevalence and clinical features of psoriatic arthritis and joint complaints in 2009 patients with psoriasis: results of a German national survey. J Eur Acad Dermatol Venereol 2009, 23, 683-691.

6. Augustin M., Eissing L., Langenbruch A., Enk A., Luger T., Maaßen D., et al.: The German National Program on Psoriasis Health Care 2005-2015: results and experiences. Arch Dermatol Res 2016, 308, 389-400.

7. Taylor W., Gladman D., Helliwell P., Marchesoni A., Mease P., Mielants H.; CASPAR Study Group: Classification criteria for psoriatic arthritis: development of new criteria from a large international study. Arthritis Rheum 2006, 54, 2665-2673.

8. Strohal R., Kirby B., Puig L.; Psoriasis Expert Panel: Psoriasis beyond the skin: an expert group consensus on the management of psoriatic arthritis and common co-morbidities in patients with moderate-to-severe psoriasis. J Eur Acad Dermatol Venereol 2014, 28, 1661-1669.

9. Boehncke W.H., Boehncke S., Tobin A.M., Kirby B.: The "psoriatic march": a concept of how severe psoriasis may drive cardiovascular comorbidity. Exp Dermatol 2011, 20, 303-307.

10. Coimbra S., Catarino C., Santos-Silva A.: The triad psoriasis-obesity-adipokine profile. J Eur Acad Dermatol Venereol 2016, 30, 1876-1885.

11. Armstrong E.J., Harskamp C.T., Armstrong A.W.: Psoriasis and major adverse cardiovascular events: a systematic review and meta-analysis of observational studies. J Am Heart Assoc 2013, 2, e000062.

12. Miller I.M., Ellervik C., Yazdanyar S., Jemec G.B.: Meta-analysis of psoriasis, cardiovascular disease, and associated risk factors. J Am Acad Dermatol 2013, 69, 1014-1024.

13. Piepoli M.F., Hoes A.W., Agewall S., Albus C., Brotons C., Catapano A.L., et al.: Wytyczne ESC dotyczące prewencji chorób układu sercowo-naczyniowego w praktyce klinicznej w 2016 roku. Kardiol Pol 2016, 74, 821-936.

14. Mrowietz U., Kragballe K., Reich K., Spuls P., Griffiths C.E., Nast A., et al.: Definition of treatment goals for moderate to severe psoriasis: a European consensus. Arch Dermatol Res 2011, 303, 1-10. 
15. Armstrong A.W., Tuong W., Love T.J., Carneiro S., Grynszpan R., Lee S.S., et al.: Treatments for nail psoriasis: a systematic review by the GRAPPA Nail Psoriasis Work Group. J Rheumatol 2014, 41, 2306-2314.

16. Norsgaard H., Kurdykowski S., Descargues P., Gonzalez T., Marstrand T., Dünstl G., et al.: Calcipotriol counteracts betamethasone-induced decrease in extracellular matrix components related to skin atrophy. Arch Dermatol Res 2014, 306, 719-729.

17. van de Kerkhof P.C., van der Valk P.G., Swinkels O.Q., Kucharekova M., de Rie M.A., de Vries H.J., et al.: A comparison of twice-daily calcipotriol ointment with once-daily short-contact dithranol cream therapy: a randomized controlled trial of supervised treatment of psoriasis vulgaris in a day-care setting. Br J Dermatol 2006, 155, 800-807.

18. Weinstein G.D., Krueger G.G., Lowe N.J., Duvic M., Friedman D.J., Jegasothy B.V., et al.: Tazarotene gel, a new retinoid, for topical therapy of psoriasis: vehicle-controlled study of safety, efficacy, and duration of therapeutic effect. J Am Acad Dermatol 1997, 37, 85-92.

19. Roelofzen J.H., Aben K.K., Oldenhof U.T., Coenraads P.J., Alkemade H.A., van de Kerkhof P.C., et al.: No increased risk of cancer after coal tar treatment in patients with psoriasis or eczema. J Invest Dermatol 2010, 130, 953-961.

20. Wollina U., Koch A., Scheibe A., Seme B., Streit I., Schmidt W.D.: Targeted $307 \mathrm{~nm}$ UVB-excimer light vs. topical dithranol in psoriasis. J Eur Acad Dermatol Venereol 2012, 26, 122-123.

21. Higgins E., Ralph N., Ryan S., Koik N., Honari B., Lally A., et al.: A randomized half body prospective study of low and medium dose regimens using the $308 \mathrm{~nm}$ excimer laser in the treatment of localised psoriasis. J Dermatolog Treat 2017, 28, 8-13.

22. Pfaff S., Liebmann J., Born M., Merk H.F., von Felbert V.: Prospective randomized long-term study on the efficacy and safety of UV-free blue light for treating mild psoriasis vulgaris. Dermatology 2015, 231, 24-34.

23. Luger T.A., Cambazard F., Larsen F.G., Bourcier M., Gupta G., Clonier F., et al.: A study of the safety and efficacy of calcipotriol and betamethasone dipropionate scalp formulation in the long-term management of scalp psoriasis. Dermatology 2008, 217, 321-328.

24. Poulin Y., Papp K., Bissonnette R., Barber K., Kerrouche N., Villemagne H.; Calepso Study Team: Clobetasol propionate shampoo $0.05 \%$ is efficacious and safe for long-term control of moderate scalp psoriasis. J Dermatolog Treat 2010, $21,185-192$.

25. Wozel G., Klein E., Mrowietz U., Reich K., Sebastian M., Streit V.: Scalp psoriasis. J Dtsch Dermatol Ges 2011, 9, 70-74.

26. Wang T.S., Tsai T.F.: Managing scalp psoriasis: an evidence-based review. Am J Clin Dermatol 2017, 18, 17-43.

27. Kroft E.B., Erceg A., Maimets K., Vissers W., van der Valk P.G., van de Kerkhof P.C.: Tacrolimus ointment for the treatment of severe facial plaque psoriasis. J Eur Acad Dermatol Venereol 2005, 19, 249-251.

28. Lebwohl M., Freeman A., Chapman M.S., Feldman S., Hartle J., Henning A.: Proven efficacy of tacrolimus for facial and intertriginous psoriasis. Arch Dermatol 2005, 141, 1154.

29. Rich P., Scher R.K.: Nail Psoriasis Severity Index: a useful tool for evaluation of nail psoriasis. J Am Acad Dermatol 2003, 49, 206-212.

30. Rigopoulos D., Gregoriou S., Katsambas A.: Treatment of psoriatic nails with tazarotene cream $0.1 \%$ vs. clobetasol propionate 0.05\% cream: a double-blind study. Acta Derm Venereol 2007, 87, 167-168.

31. Rigopoulos D., Gregoriou S., Daniel III C.R., Belyayeva H., Larios G., Verra P., et al.: Treatment of nail psoriasis with a two-compound formulation of calcipotriol plus betamethasone dipropionate ointment. Dermatology 2009, 218, 338-341.

Received: 25.03.2018

Accepted: 26.03 .2018

Otrzymano: 25.03.2018 r.

Zaakceptowano: $26.03 .2018 \mathrm{r}$.

How to cite this article

Reich A., Adamski Z., Chodorowska G., Kaszuba A., Krasowska D., Lesiak A., Maj J., Narbutt J., Osmola-Mańkowska A., Owczarczyk-Saczonek A., Owczarek W., Placek W., Rudnicka L., Szepietowski J.: Psoriasis. Diagnostic and therapeutic recommendations of the Polish Dermatological Society. Part I: Mild psoriasis. Dermatol Rev/Przegl Dermatol 2018, 105, 225-243. DOI: https://doi.org/10.5114/dr.2018.75580. 